Nutrition Research Reviews, published annually by Cambridge University Press, presents authoritative and critical reviews of research that advance new concepts and encourage fresh thinking on a variety of nutritional problems. The journal's main objective is to encourage the exchange of fundamental ideas on nutritional well-being. The subscription (excluding VAT) to volume 9,1996 , is $£ 50$ including postage (US $\$ 90$ in USA, Canada and Mexico).

The Proceedings of the Nutrition Society, published by Cambridge University Press, in part record meetings of the Symposium type, at which experts in a particular field are invited by Council to make contributions on specific parts of it and at which general discussion follows these invited contributions. The meetings also include sessions at which papers are communicated by members and others on original work. It is proposed at present to publish summaries of the papers read at each meeting, each communication being recorded in the Society's Proceedings by means of an abstract not exceeding in length 400 words or the equivalent space in print. The Proceedings are published three times a year.

The subscription (excluding VAT) to the Proceedings is $£ 144.00$ (US $\$ 264.00$ in USA, Canada and Mexico). Single issues are $£ 53.00$ (US $\$ 98.00$ in the USA, Canada and Mexico) each; postage extra.

Copying. This journal is registered with the Copyright Clearance Center, 222 Rosewood Drive, Danvers, MA 01923. Organizations in the USA who are also registered with C.C.C. may therefore copy material (beyond the limits permitted by sections 107 and 108 of the US copyright law) subject to payment to C.C.C. of the per-copy fee of $\$ 11.00$. This consent does not extend to multiple copying for promotional or commercial purposes. Code $0007-1145 / 96 \$ 11.00+.10$. Organizations authorized by the Copyright Licensing Agency may also copy material subject to the usual conditions.

ISI Tear Sheet Service, 3501 Market Street, Philadelphia, Pennsylvania 19104, USA, is authorized to supply single copies of separate articles for private use only.

For all other use, permission should be sought from Cambridge or the American Branch of Cambridge University Press.

Information of The British Journal of Nutrition and all other Cambridge journals is available on http://www.cup.cam.ac.uk/ and in North America on http://www.cup.org/.

\title{
INDEX OF AUTHORS
}

\begin{tabular}{lr|lr|} 
Alles, M. S. & 211 & Hartemink, R. & 211 \\
Berggren, A. M. & 287 & Hautvast, J. G. A. G. & 211 \\
Björck, I. M. E. & 287 & & 295 \\
Britton, G. & 307 & Jackson, A. A. & 165,199 \\
Brown, D. S. & 231 & Jackson, M. J. & 307 \\
Calder, A. G. & 231 & Jansen, J. B. M. J. & 211 \\
Connell, A. & 231 & & 223 \\
Coustaut, M. & 295 & Key, F. B. & \\
& & Kornegay, E. T. & 273 \\
Deurenberg, P. & 175 & & 263 \\
Duggan, M. B. & 183 & Lobley, G. E. & 231 \\
& & Lundquist, I. & 287 \\
Frayn, K. N. & 157 & & \\
& & McClelland, I. S. M. & 199 \\
Garcin, H. & 295 & McIntosh, F. M. & 249 \\
Gijsbers, B. L. M. G. & 223 & McClean, D. & 273 \\
Harbottle, L. & & Mathers, J. C. & 273 \\
Hal & 183 & Milne, E. & 231
\end{tabular}

$\begin{array}{ll}\text { Nagengast, F. M. } & 211 \\ \text { Newbold, C. J. } & 249 \\ \text { Nyman, E. M. G. L. } & 287 \\ & \\ \text { Pallet, V. } & 295 \\ \text { Qian, H. } & 263 \\ \text { Stroud, M. A. } & 165 \\ & \\ \text { Van Laere, K. M. J. } & 211 \\ \text { Veit, H. P. } & 263 \\ \text { Vermeer, C. } & 223 \\ & \\ \text { Wallace, R. J. } & 249 \\ \text { Wang, J. } & 175 \\ \text { Waterlow, J. C. } & 165 \\ \text { Weijs, P. J. M. } & 231 \\ \text { Widdowson, E. M. } & 161 \\ \text { Woodall, A. A. } & 307 \\ \end{array}$




\section{CONTENTS}

\section{of Nutrition}

Editorial

Nutritionists as guinea-pigs. K. N. Frayn

$157-159$

An appreciation

Alice Mary Copping (1906-1996). E. M. Widdowson

$161-163$

\section{Human and Clinical Nutrition}

Protein turnover rates of two human subjects during an unassisted crossing of Antarctica. M. A. Stroud, A. A. Jackson \& J. C. Waterlow

The validity of predicted body composition in Chinese adults from anthropometry and bioelectrical impedance in comparison with densitometry. Jingzhong Wang \& Paul Deurenberg

The growth and nutritional status of healthy Asian children aged 4-40 months living in Sheffield. M. B. Duggan \& L. Harbottle

Urea kinetics in healthy young women: minimal effect of stage of menstrual cycle, contraceptive pill and protein intake. Irene S. M. McClelland \& Alan A. Jackson

Fate of fructo-oligosaccharides in the human intestine. Martine S. Alles, Joseph G. A. J. Hautvast, Fokko M. Nagengast, Ralf Hartemink, Katrien M. J. Van Laere \& Jan B. M. J. Jansen

Effect of food composition on vitamin $\mathrm{K}$ absorption in human volunteers. Birgit L. M. G. Gijsbers, Kon-Siong G. Jie \& Cees Vermeer

Animal Nutrition

The fate of absorbed and exogenous ammonia as influenced by forage or forage-concentrate diets in growing sheep. G. E. Lobley, P. J. M. Weijs, A. Connell, A. G. Calder, D. S. Brown \& E. Milne

Mode of action of the yeast Saccharomyces cerevisiae as a feed additive for ruminants. C. J. Newbold, R. J. Wallace \& F. M. Mclntosh

Effects of supplemental phytase and phosphorus on histological, mechanical and chemical traits of tibia and performance of turkeys fed on soyabean-meal-based semi-purified diets high in phytate phosphorus. H. Qian, E. T. Kornegay \& H. P. Veit

\section{General Nutrition}

Tissue hypertrophy and epithelial proliferation rate in the gut of rats fed on bread and haricot beans (Phaseolus vulgaris). Fiona B. Key, Devina McClean \& J. C. Mathers

Influence of orally and rectally administered propionate on cholesterol and glucose metabolism in obese rats. Anna M. Berggren, E. Margareta G. L. Nyman, Ingmar Lundquist \& Inger M. E. Björck

The influence of dietary vitamin $A$ on triiodothyronine, retinoic acid, and glucocorticoid receptors in liver of hypothyroid rats. M. Coustaut, V. Pallet, H. Garcin \& P. Higueret

Dietary supplementation with carotenoids: effects on $\alpha$-tocopherol levels and susceptibility of tissues to oxidative stress. Alan A. Woodall, George Britton \& Malcolm J. Jackson

Announcements 